\title{
Landing facilities for processing of cultivated seaweed biomass: a Norwegian perspective with strategic considerations for the European seaweed industry
}

\author{
Pierrick Stévant ${ }^{1}\left[\right.$ ] Céline Rebours $^{1}$
}

Received: 8 April 2021 / Revised and accepted: 2 June 2021 / Published online: 6 July 2021

(c) The Author(s) 2021

\begin{abstract}
The production of marine biomass based on seaweed cultivation is growing rapidly in Europe. One of the major challenges for the development of this new industry is associated with processing of the wet biomass harvested from cultivation sites. Efficient methods for the stabilization (i.e. procedures to maintain the integrity and safety of the biomass) and further processing of large quantities of harvested raw material are still lacking as the development of adapted technologies is often limited by significant capital investment. This study investigates the concept of landing facilities for the processing of cultivated seaweed biomass (LFCS) shared among various stakeholders as a practical mean to overcome these challenges. Qualitative data were collected during interviews with relevant stakeholders from Norway and abroad (including seaweed cultivators, technology suppliers and industrial buyers of biomass) to describe the current commercial applications for cultivated seaweeds as well as the methods used for the stabilization and processing of the biomass. This study showed that LFCS can give stakeholders the opportunity to share the costs (investment, operational), thus lowering the financial threshold for establishing efficient strategies for processing large quantities of cultivated seaweed biomass. It was identified that such a structure will increase the synergy among industrial actors along the entire value chain to stimulate innovation and facilitate the production of high-quality products from seaweeds to relevant markets (food, animal feed, nutraceuticals and cosmetics). It can also lead to a higher degree of specialization in this new industry. These premises will contribute to increase the profitability of the emerging European seaweed sector. Identification of the appropriate stabilization processes for large-scale production, definition of the role of LFCS in the seaweed value chain as well as the mode of engagement of the stakeholders in such structure are thus acknowledged as key considerations to define during the planning phase.
\end{abstract}

Keywords Seaweed $\cdot$ Processing $\cdot$ Large-scale production $\cdot$ Value chain $\cdot$ Stabilization

\section{Introduction}

As the world population is expected to increase to over 9 billion people within the next 40 years there is a growing pressure to produce sustainable alternative sources of food, drugs and chemicals (Barbier et al. 2020; Rotter et al. 2020). Increasing agricultural production is often associated with ecosystem deterioration such as deforestation, reduced biodiversity and eutrophication of aquatic systems. Strategies to meet this demand tend to favor the development of value chains linked to renewable resources; reduced environmental

Pierrick Stévant

pierrick.stevant@moreforsking.no

1 Møreforsking AS, PO Box 5075, 6021 Ålesund, Norway impacts including carbon emissions, to support global actions against climate change; and the utilization of the entire biomass produced. In this context, marine organisms and especially seaweeds are considered a promising resource for (i) the sustainable production of food and animal feed, cosmetics and nutraceuticals and (ii) the production of biopolymers and biomaterials (Rotter et al. 2020).

Seaweed biomass can be cultivated on a large scale in coastal areas without competing for fresh water or soil resources. The productivity of some species like kelps exceeds those of agricultural plant production (Bruhn et al. 2016). The global seaweed production (32.3 million $t$ in 2018) mainly takes place in Asian countries while $5300 \mathrm{t}$ of seaweed was cultivated in Europe in 2018, representing less than $0.02 \%$ of the total volume produced globally, with a value of US\$ 9.6 million (FAO 2021a). Although this is 
an emerging industry in Europe, it is expected to grow following current trends promoting natural and sustainable feedstocks to commercial applications (e.g. food and animal feed) according to international strategies for sustainable industrial development (Barbier et al. 2020; Araújo et al. 2021). In addition, seaweed cultivated in proximity to fish farms in so-called integrated multi-trophic aquaculture (IMTA) systems represents a practical solution for mitigating the negative effects of fish farming wastes by utilizing dissolved nutrients as a valuable resource for macroalgal production (Neori et al. 2004; Knowler et al. 2020).

Norway has a long coastline as well as competence and infrastructure related to the production and processing of marine resources (e.g. farmed salmon and trout). Moreover, Norway has established an industrial production based on harvesting wild seaweed stocks, representing approx. $60 \%$ of the wild-harvested seaweed biomass in Europe (FAO 2021b), and developed know-how related to processing seaweed biomass. The cultivation of seaweeds, primarily sugar kelp (Saccharina latissima) and winged kelp (Alaria esculenta), is in rapid development as part of the national strategy to develop a bioeconomy based on the production of renewable biomass (Stévant et al. 2017b). Despite a growing interest from private stakeholders and public authorities to develop the industry, commercial outputs from cultivated seaweed biomass remain limited (ranging from 51 to $178 \mathrm{t}$ wet biomass per year between 2015 and 2019 (Directorate of Fisheries 2020)). Large-scale seaweed cultivation entails several technical and logistical challenges which need to be addressed to realize the potential of this emerging industry. This includes handling, processing and storage of large volumes of biomass. One of the main challenges for producers is to maintain the quality of seaweeds after harvesting due to a high water content (70 to $90 \%$ of the wet weight) and rapid biodegradation. The suitability of processing methods depends not only on the quality of the end-product but also on energy requirements as well as associated investment and operating costs. Optimized, sustainable and profitable processing strategies for delivering high-quality products from seaweeds to relevant industrial applications (e.g. human food and animal feed) have been identified as a prerequisite for future industrial developments (Philis et al. 2018; Emblemsvåg et al. 2020).

Adapted technology for the conservation and further processing of marine raw material is often associated with high capital investment. This is today a major bottleneck limiting the development of an aquaculture-based seaweed industry in Europe (Emblemsvåg et al. 2020). In this context, establishing landing facilities for cultivated seaweed (LFCS) for biomass stabilization and processing at a commercial scale may be a rational solution to overcome this challenge. Based on qualitative data collected during interviews with relevant private stakeholders (seaweed cultivators, technology suppliers and industrial buyers of biomass), current commercial applications, methods for receiving and conserving biomass and challenges associated with seaweed processing were identified. The aim of this study is to provide an outline for establishing efficient solutions for processing large volumes of cultivated seaweeds. This will support the necessary industrialization and provide further opportunities for the sustainable development of the seaweed industry in Norway and at large in Europe.

\section{Material and methods}

\section{Data collection: semi-structured interviews}

Semi-structured interviews were chosen as a suitable method to obtain detailed information on opinions and attitudes regarding industrial processing of seaweeds and establishing a LFCS. Research interviews enable an in-depth study of complex behavior and motivation by collecting a variety of meanings, opinions and practices. The method is adapted from the one used in a previous study to identify problems and stakeholders' concerns regarding the development of IMTA to a commercial production level (Alexander et al. 2016).

Twelve interviews were conducted between July and September 2020 with a selection of stakeholders related to the seaweed industry. Relevant interviewees were identified from previous research projects related to seaweed processing as well as from the author's own network. The stakeholders belong to 3 different groups covering the value chain, i.e. seaweed farmers, technology suppliers and commercial users of cultivated biomass. The former group was more widely represented in the selection for the purpose of the study. The main part of the selection consisted of established actors in their respective sectors, focusing on industrialization (i.e. not newly established companies with little experience). Most of the interviewees were selected from Norwegian businesses, but two were seaweed cultivators from other European countries (Table 1).

The interviewed seaweed producers from Norway and abroad $(n=7)$ consisted of companies with established

Table 1 Number of interviews per stakeholder group, from Norway and abroad

\begin{tabular}{lll}
\hline & Norway & $\begin{array}{l}\text { Other } \\
\text { European } \\
\text { countries }\end{array}$ \\
\hline Seaweed cultivators & 5 & 2 \\
Technology suppliers & 3 & 0 \\
Industrial users & 2 & 0 \\
Total & 10 & 2 \\
\hline
\end{tabular}


production between 2013 and 2017, mainly of S. latissima and $A$. esculenta. The reported production volume from these industrial players in 2020 varies between 15 and $150 \mathrm{t}$ of fresh biomass. Two companies were also involved in the production of other species such as sea lettuce (Ulva spp.). The technology suppliers $(n=3)$ consisted of companies specialized in drying wet raw materials. Two of them had experience with drying seaweed biomass. Representatives from large companies in the food and feed industry $(n=2)$ present on international markets were interviewed as possible commercial users of cultivated biomass. Both had experience with using seaweed in food and feed formulations, respectively, at a research and development stage.

Qualitative data were collected during semi-structured interviews using an interview guide. The guide contained 11 questions divided into 4 sections. The first section depicts the actors' background and relationship to seaweed as well as their role in the value chain. The second section identified which markets the stakeholders are connected to and what requirements (quality and volume) the various applications have for seaweed biomass. Section 3 focused on methods and technology used in the seaweed industry for stabilizing harvested biomass, the participants' experience with relevant processes and their needs for new or improved methods. The last section investigated the participants' opinions about cooperation with other actors of the seaweed value chain and their interest in a LFCS.

Information about the project and the interview questions were sent to the participants beforehand. The interviews took place as video conferences using Microsoft Teams. Informed consent was obtained from the participants. The interviews were recorded and later transcribed. The interview respondents were given the opportunity to review, modify and/or delete information from the transcripts.

\section{Data analysis}

The analysis of qualitative data follows 3 main processes: data reduction, data display and conclusions (Miles et al. 2014). The interview transcripts were formatted and imported into the NVivo 12 software (version 1.3, QSR International, UK) for coding and sorting qualitative data. The interview data were reduced and grouped into specific categories related to (i) the main topics described above and (ii) stakeholder groups. The reduced data were subsequently organized into matrices so that trends and patterns individually and across groups could easily be identified and compared, and conclusions be drawn. Important direct quotes from interviewees were translated into English.

Data from the interviews were processed according to the General Data Protection Regulation (GDPR). Names and other key information about individuals or companies were deleted from the transcripts to ensure anonymity of the collected data. The project and the data processing plan were approved by the Norwegian Centre for Research Data (www.nsd.no, reference: 463,969).

\section{Results}

\section{Stakeholders' roles in the value chain}

From the interviews, it emerged that seaweed producers are involved in the value chain at different levels. Some cover the whole range from biomass production to the development of finished products while others only focus on cultivation and primary processing (i.e. stabilization) of the produced biomass (Table 2). A few interviewed players are also involved in seedling production and sales, and in the development of cultivation technology. Working along the entire value chain is perceived negatively by some while it is considered convenient for others. The major disadvantage is that a lot of resources and focus are required to succeed within the various segments in the value chain while, for others, it provides flexibility for managing the production and product portfolio.

"It is not optimal, but the reality is that we are doing everything now".

"That is the beauty, we are throughout the whole value chain. We grow our own seaweed [...]. We process. We do product development. We run trials. We do retail. And retail for food, fertilizer, pharma, health supplements, so it is really A to Z".

(Seaweed cultivators)

Nevertheless, the interviewed technology suppliers reported to have an interest in assisting the seaweed industry with the development of drying technology adapted to the raw material and end-products, from pilot to large scale. Commercial users (food and feed producers) are willing to position themselves as buyers of large quantities of either raw material (e.g. fresh, dried or fermented), that can be further processed as required, or refined products from cultivated seaweeds (e.g. fraction or extract) which can be used as ingredients in a formulation.

\section{Applications and associated requirements for biomass quality and quantity}

All seaweed cultivators mentioned food as an important market (Table 2). Interviewees from this group reported using all $(n=3 / 7)$ or part of their production $(n=4 / 7)$ for food applications. This includes sales of large quantities (bulk) to other companies manufacturing food products containing seaweed as an ingredient as well as specific products, 
Table 2 Reduced data from interviews on the role of stakeholders in the value chain and connection to markets for cultivated seaweeds

\begin{tabular}{|c|c|c|c|}
\hline & Seaweed cultivators $(n=7)$ & Technology suppliers $(n=3)$ & Industrial users $(n=2)$ \\
\hline Stakeholders role in the value chain & $\begin{array}{l}\text { - Production, primary processing } \\
\text { (biomass stabilization) }(7 / 7) \\
\text { - Product development, distribution } \\
\text { and sales }(2 / 7) \\
\text { - Development of cultivation and } \\
\text { harvesting technology }(1 / 7) \\
\text { - Seedling production and sales } \\
\text { (1/7) }\end{array}$ & $\begin{array}{l}\text { - Development of drying } \\
\text { technology adapted to } \\
\text { seaweed raw material } \\
(3 / 3)\end{array}$ & $\begin{array}{l}\text { - Buyer of seaweed raw material }(1 / 2) \\
\text { - Buyer of refined product from sea- } \\
\text { weed (e.g. extract) }(1 / 2)\end{array}$ \\
\hline $\begin{array}{l}\text { Which applications and markets are } \\
\text { they involved in? }\end{array}$ & $\begin{array}{l}\text { - Food (7/7) } \\
\text { - Animal feed (4/7) } \\
\text { - Cosmetics and well-being (3/7) } \\
\text { - Nutraceuticals }(1 / 7) \\
\text { - Fertilizers }(1 / 7)\end{array}$ & & $\begin{array}{l}\text { - Food products to the mass market } \\
\text { (i.e. not niche products) }(1 / 2) \\
\text { - Animal feed }(1 / 2)\end{array}$ \\
\hline $\begin{array}{l}\text { What quality requirements are they } \\
\text { subject to/do they set? }\end{array}$ & 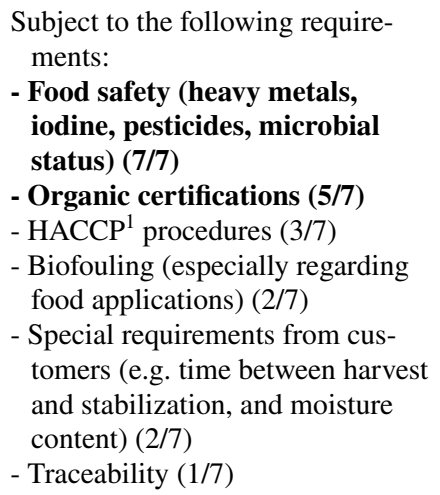 & $\begin{array}{l}\text { Generally, it depends on } \\
\text { the product applica- } \\
\text { tion. Requirements often } \\
\text { includes: } \\
\text { - Food safety }(\mathbf{2} / \mathbf{3}) \\
\text { - Minimal oxidation and } \\
\text { color changes }(1 / 3) \\
\text { - Moisture content below } \\
10 \%(1 / 3) \\
\text { - No stones or sand }(1 / 3)\end{array}$ & $\begin{array}{l}\text { Set requirements to: } \\
\text { - Stable quality }(1 / 2) \\
\text { - Nutrient content, e.g. minimum level } \\
\text { of protein and } \omega-3 \text { fatty acids }(1 / 2) \\
\text { - Liquid or powder form }(1 / 2) \\
\text { - Food safety (heavy metals, iodine, } \\
\text { microbial status, allergens) }(1 / 2) \\
\text { - Flavor and appearance }(1 / 2)\end{array}$ \\
\hline $\begin{array}{l}\text { What requirements for biomass } \\
\text { volume are the subject to/do they } \\
\text { set? }\end{array}$ & $\begin{array}{l}\text { Subject to the following require- } \\
\text { ments: } \\
\text { - Requirements for quantity still } \\
\text { undefined due to market being } \\
\text { under development }(3 / 7) \\
\text { - Stable delivery }(1 / 7)\end{array}$ & & $\begin{array}{l}\text { Set requirements to: } \\
\text { - Large quantity }(102 \mathrm{t} \text { fresh bio- } \\
\text { mass) }(2 / 2) \\
\text { - Stable supply }(2 / 2)\end{array}$ \\
\hline
\end{tabular}

The sentences in bold were raised by more than $50 \%$ of the interviewees within a group

${ }^{1}$ HACCP Hazard Analysis Critical Control Point

e.g. dried kelp seasoning, developed internally by seaweed producers. Although the quantities of biomass traded as food product or ingredients may be small for some producers, this application is identified repeatedly for its potential for value creation.

"Not biggest in volume but biggest in value added".

“... those who pay best. Mainly as food ingredients and such things".

(Seaweed cultivators)

Animal feed is also an important application which more than $50 \%$ of the interviewed seaweed producers are associated with to a certain degree (Table 2). Seaweed biomass may be sold as an ingredient in both food and feed applications in different forms, i.e. dried, fermented or frozen. The respondents from the group consisting of commercial users of seaweed biomass mentioned dried material as a convenient form to work with, due to e.g. a long shelf-life. The interviewee from the food industry has so far only tested dried material in product development but does not exclude other forms (fermented, frozen) in the near future if the seaweed material meets their quality requirements. The respondent from the feed industry had even more specific requirements for seaweed ingredients which must be delivered in "either liquid or in powder form with a certain moisture content" to be further used in feed formulations.

Cosmetics and well-being were identified as profitable applications for cultivated seaweeds. Both respondents from outside Norway trade a significant part of their production towards these applications. Both dried and fresh material may be used in various products such as facial creams and spa treatments. Among the Norwegian respondents, only one producer reported selling a small fraction of its production towards cosmetic applications.

Sustainability aspects and the environmental benefits associated with seaweed cultivation are explicitly mentioned as important factors for the industrial users' interest in this resource as food and feed ingredients. Positive values such 
as the production at sea without using pesticides and synthetic fertilizers as well as local or national identity (which may replace imported raw material) can be used for the marketing of seaweed-based end-products. At the same time, the total utilization of the produced biomass is considered an important prerequisite for sustainability in the value chain.

"Now there is much focus on sustainability, animal welfare, species diversity, etc. and I think that this can be used to build the story around seaweed".

"We want to use it. We know that seaweed is a good resource and that there is a great sustainability story around it. It is a raw material that can be produced locally or at least in Europe which perhaps is more interesting than before [...]. But we also must look at the carbon footprint of a compound from seaweed that is used. If everything else is discarded, then the sustainability story is not so good anymore".

(Industrial users of seaweed biomass from the food and feed industries)

Using cultivated seaweeds in food applications entails strict standards for the quality of the raw material to be used in the end-product (Table 2). Primarily, biomass producers must document food safety and comply with limit values for heavy metals, iodine and microbiological criteria. In addition, a large proportion of the interviewed producers are awarded organic certification under the Norwegian or European framework. This entails requirements associated with handling and processing of the biomass (e.g. rinsing after harvest and packaging). Additional requirements on how the biomass is handled or specific quality aspects can also be imposed by the distributor and customer. The respondent from the food industry pointed out that product taste is a critical obligation to create positive attitude among Western consumers for seaweeds as food and build upon the popularity of Asian seaweed-based dishes. This is a key factor to successfully include this resource in everyday food products in Norway and Europe.

"The product can be super-healthy and sustainable, if it does not taste great, it will not succeed. [...]. We must work in the near future to make better specifications for seaweed ingredients to meet high standards for food quality. This is what we do with all the raw materials we use. We have specifications related to product color, flavor, nutrient content, limit values for relevant toxic compounds, microbiology, etc.”.

(Industrial user of seaweed biomass from the food industry)

The industrial use of seaweed biomass as feed ingredient also entails strict requirements for product safety. Nevertheless, feed applications are described by several seaweed cultivators as somehow less demanding in terms of quality standards on the raw material, e.g. moisture content and presence of biofouling organisms to a certain level. From the feed industry's perspective, seaweed can be included in formulations in different ways. As a nutritional ingredient, the feed manufacturer will require a certain level of proteins and fats (Table 2) which may be limited in cultivated kelp species (S. latissima and A. esculenta) compared to other feed sources (soybean, fish, microalgae). In addition, the relatively indigestible carbohydrate fraction of kelp biomass was mentioned as a disadvantage in this context. This fraction may rather be used in feed products as a binder or as a functional ingredient with prebiotic and probiotic effects. Cultivated kelp, especially fermented raw material, was considered to be of interest for further testing by the respondent from the feed industry.

When asked about the requirements in quantity of seaweed biomass, several producers answered that the demand for large volumes is currently limited in Norway and Europe since the market for seaweed raw material is under development. "Very little demand for seaweeds on the Norwegian market" was confirmed by the respondent from the food industry. Nevertheless, it appeared that the national production must increase significantly to provide a steady supply of seaweed raw material as ingredients to large industrial actors of the food and/or feed industry if seaweed is to be incorporated in a commercial product. Another prerequisite is that the raw material must be price-competitive in order to be attractive as an ingredient in a larger perspective than today.

"We want to make it available to the mass marked. [...]. If we are to put a few percent seaweed in a typical product, it will require almost the entire volume cultivated today in Norway. This will require a significant upscale of the production as well as efficiency throughout the entire value chain. The price of seaweed ingredients is also an important factor".

(Industrial user of seaweed biomass from the food industry)

\section{Stabilization methods for seaweed biomass}

Most seaweed producers interviewed use either drying or lactic acid fermentation (also referred to as ensiling) as the main method for preserving biomass (Table 3). Three out of 7 producers use exclusively one of the two methods while the rest of the respondents use a combination of several methods. When drying, low temperature $\left(<45^{\circ} \mathrm{C}\right)$ and various systems are used such as convective air-drying on shelves, freeze-drying as well as a combination of fans and dehumidifiers. For most actors, fermentation was introduced as a new method for the preservation of large quantities of kelp biomass. Three out of 7 respondents use fermentation as the main stabilization method. During the process, 


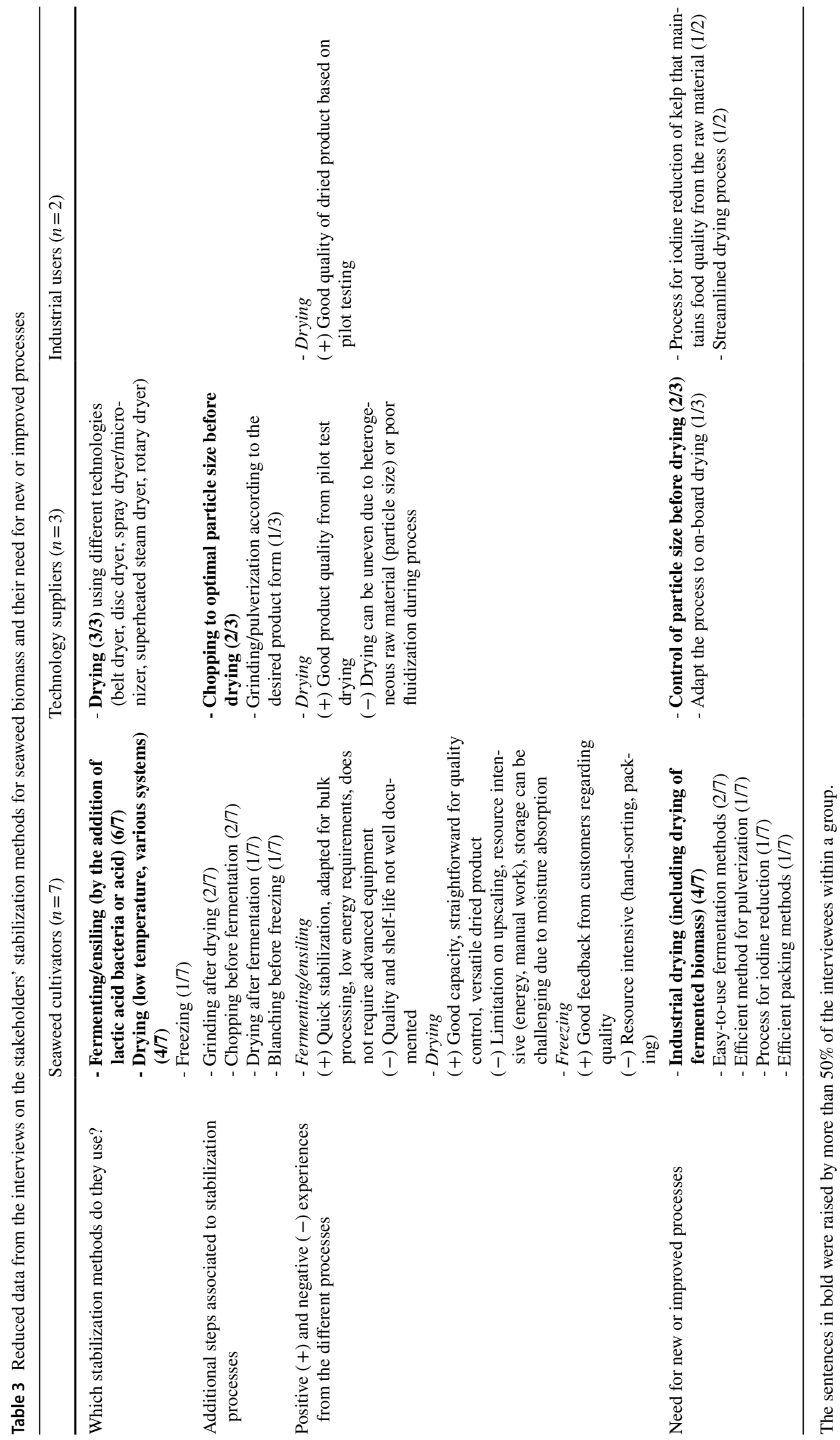


harvested biomass is added to a mixture of lactic acid bacteria to lower the $\mathrm{pH}$ under anaerobic conditions. Direct use of acid was only reported by one actor. An attempt was made to estimate how much biomass was treated by the different reported stabilization methods. Based on the figures given by 6 macroalgae producers (from both Norway and abroad) who harvested a total of $260 \mathrm{t}$ of S. latissima and A. esculenta in $2020,68 \%$ of the biomass was stabilized by fermentation while drying and freezing were used for $16 \%$ and $15 \%$ of the total, respectively. It should be noted that there is a large variation in the amount of biomass produced among the respondents ( 15 to $150 \mathrm{t}$ ) which can affect this result and may provide a skewed representation of the stabilization processes used in the Norwegian and European seaweed industry in general.

In total, 6 out of 7 seaweed producers have experience with fermentation and ensiling processes to varying degrees (Table 3). In general, they have relatively little practical background with this type of process but, so far, they have a positive experience with it. The process is described as fast and efficient for stabilizing large quantities, and it is adapted to the mechanized harvest of the biomass by e.g. on-board processing and reduces the need for manual work. However, the quality and shelf-life of fermented kelp has not been well documented yet. Several actors (4 of 7) also have experience with drying but have divided opinions about this process. Some claim that they have a good capacity for processing their production by drying and the possibility of good quality control during the process. Dried seaweeds are versatile and stable and can be used in a broad range of commercial applications. Others point out the limitations of the process for the preservation of large volumes of seaweed biomass in the context of upscaling the production. This is mainly due to the high energy demand and need for manual handling during the process as well as the need for controlling the conditions during dry storage to avoid absorption of moisture. One of the seaweed producers uses freezing as the main method of conserving biomass (Table 3). This choice is driven by quality requirements from customers. The disadvantage of the method is the need for manual work when hand-sorting and packing. This labor-intensive disadvantage was confirmed by another producer who had previously used freezing as a stabilization method in commercial kelp production.

"Transporting the biomass on land and freezing cost up to 15 NOK [ca. 1.7 US\$] per kilo only in working hours".

(Seaweed cultivator)

Other processes associated with the stabilization of cultivated seaweeds include grinding or pulverization after drying, chopping before fermentation, drying of fermented material and blanching before freezing.
The interview respondents were asked about their need for new or improved technical solutions for stabilizing raw materials. Most seaweed producers reported lacking efficient methods for industrial drying (Table 3) and indicated requirements specifically to the drying of fermented raw material and the on-board drying of freshly harvested biomass.

"There is a lack of good drying opportunities locally".

"When it comes to drying, we have no good industrial drying methods".

"We need to be able to centralize the drying process".

(Seaweed cultivators)

Some cultivators consider the development of efficient and easy-to-use solutions for fermentation of large biomass volumes as necessary to scale up the production. Another challenge identified during the interviews is associated with mechanical grinding of A. esculenta in both fresh and dried forms due to its tough midrib. In addition, kelp species typically contain high levels of iodine, which can be a problem when using the biomass in food and feed applications. The need for developing solutions for iodine reduction was therefore mentioned. This reflected the statement of the interviewed stakeholders from the food industry emphasizing the importance of introducing "controllable amounts [of iodine] in foods that people are likely to eat every day" to ensure that food safety for the user is maintained while developing tasty and nutritious food ingredients from seaweeds.

"When reducing iodine which is water-soluble, it is important that we do not wash-out flavor compounds and other water-soluble nutrients and bioactives".

(Industrial user of seaweed biomass from the food industry)

The interviewed technology suppliers have expertise in various drying technologies adapted to industrial treatment of wet material with a focus on gentle treatment of the raw material, energy saving (heat recovery) and flexibility (mobile drying plant). Technology suppliers who have experience with kelp drying ( 2 of 3 ) point out the pretreatment of biomass by chopping as critical for achieving even particle size and optimal drying of the raw material (Table 3).

\section{Collaboration and interest in a LFCS}

The interviews attempted to map which types of collaboration are envisioned by various stakeholders to solve the current challenges associated with processing of seaweed biomass towards product development. For seaweed producers, it was most important to collaborate with:

- Equipment supplier for drying the raw material $(n=3 / 7)$ 
- Stakeholders (research, private company) with knowledge in fermentation $(n=2 / 7)$

- Industrial users of seaweed biomass to identify existing and potential future customers for targeted product development and optimization of process towards end-product $(n=2 / 7)$

- Other seaweed cultivators to be able to handle larger quantities efficiently $(n=2 / 7)$

Respondents from both the food and feed industries consider the collaboration with seaweed producers as an important factor for optimal product development. Both are also engaged in ongoing collaborations with one or several research institutions regarding the use and processing of seaweed biomass in food and feed applications. One respondent specifically mentioned the collaboration between industrial actors and the research community as important "for realizing the potential of seaweeds". All suppliers of drying technology envisage to collaborate with other suppliers of industrial processing equipment to put together optimal processes. One of them points out that dialogue with biomass producers to define their markets is essential for developing targeted processes and delivering high-quality products at acceptable costs.

"An important prerequisite is to define what type of product is wanted at the end, with regards to the final application and e.g. particle size. This is important to identify the economic potential at the end of the valuechain and to target the process".

(Technology supplier)

The interviewees showed a generally positive attitude towards the concept of LFCS. Sharing the investment, operating and infrastructure costs is considered by biomass producers (5 of 7) as the biggest advantage of participating in such a plant. This is regarded as positive for the seaweed industry in general and particularly for smaller producers who do not have the resources to invest in processing equipment and who will benefit from such a plant for processing their production. Thus, the industry will "be able to supply larger volumes" (seaweed cultivators) to the market. A producer emphasizes that competence across sectors can solve current challenges in the seaweed industry. This respondent also suggests that public support may increase the attractivity for private stakeholders to invest resources for realizing the concept of LFCS.

"The benefits would be to bring in knowledge from different sectors into one facility that can address certain issues that oneself alone wouldn't solve".

"It is important to ensure quality. We developed our standards on how the biomass should be transported, in terms of temperature, storage time [...]. For us it is important that the product [from the LFCS] is as good as what we produce ourselves".

(Seaweed cultivators)

Although the concept of LFCS aroused interest among seaweed cultivators, several respondents ( 3 of 7 ) emphasize that transport time is a critical factor. A facility located in a specific region may not be attractive for producers located at a distance higher than a few hours of transport time. Due to the rapid degradation of the kelp biomass once harvested, their interest in such a plant will depend on the distance between the cultivation site and the facility as well as technical solutions for short-term storage of the biomass between harvest and processing, e.g. cold storage or fermentation.

"A transport time [of fresh biomass] exceeding 2 hours would be too long".

"The main challenge is to stabilize the biomass immediately after harvest. It could be a model where the reception plant delivers a kind of setup for fermentation with e.g. large tanks or containers. Then the biomass is sent there to be processed further".

(Seaweed cultivators)

The seasonality of the activities based on the cultivation and processing of seaweeds is pointed out by some producers (2 of 7) as a challenge for the profitable operation of such a plant. Developing techniques for the fermentation of large volumes of biomass before further processing is proposed as a solution to extend the production season. Several operating models for the facility were also proposed by the interviewees, such as a cooperative (like e.g. wine cooperatives) where cultivators deliver their production and get back a quantity of processed product of a certain quality. Alternatively, a privately owned company can operate the LFCS and rent out equipment to the producers for processing biomass after harvest. The use of the facility can also be extended to the processing of raw materials from other sectors (e.g. agriculture, fisheries and aquaculture) when cultivated seaweed biomass is not available.

The suppliers of drying technology were all positive to the concept of such a facility where they will be able to contribute to the development of adapted processes to the emerging seaweed industry. They also highlight the need for profitability on a short term to finance process development from pilot to large scale. Both respondents from the food and feed industries believe that LFCS can give the seaweed industry the opportunity to upscale the national production to the levels they require to use the raw material in their respective production processes. As potential buyers of seaweed biomass, they will not have the main role in the plant but rather define quality requirements and advise towards product development. One respondent specifically mentioned that the whole process (from harvest to retail) must be 
as efficient as possible with reduced costs for manufacturers in order to guarantee the production of seaweed ingredients at a competitive price.

\section{Discussion}

\section{Current value chain of the Norwegian seaweed industry and industrial prospects}

This study investigated the concept of LFCS as a solution to overcome challenges related to large-scale processing of seaweed biomass. The industrialization of seaweed cultivation has gained priority in Europe and especially in Norway over the past decade (Stévant et al. 2017b; Barbier et al. 2020). In Norway, since the first commercial permit for seaweed farming at sea was granted in 2014, the total allocated area has increased rapidly along the coast, currently reaching over 900 ha (Directorate of Fisheries 2021). However, the annual volumes of biomass produced in Norway remain limited (Fig. 1A). This is partly due to the fact that a large proportion of the companies involved in seaweed aquaculture are in a start-up phase and do not have access to efficient technology for the production and stabilization of large quantities of biomass to make full use of the allocated production area. Accessing profitable markets for cultivated seaweed is also a priority for seaweed producers in Norway which is likely another reason for a currently low production output. Figure $1 \mathrm{~B}$ shows a tripling of the sales value for cultivated seaweeds between 2018 and 2019, although the production volume decreased, which may indicate that the industry is succeeding with product development and establishing collaboration with industrial users of the biomass. Production data reported by 5 Norwegian seaweed cultivators in this study, i.e. $245 \mathrm{t}$ of $S$. latissima and A. esculenta in 2020 , suggests an increase in the national production compared to previous years.

Most of the interviewed producers are involved in several parts of the value chain (schematized in Fig. 2), from the development of cultivation technology to product development, manufacturing and retail. This reflects a low level of specialization in this emerging industry. Based on reported data to the Directorate of Fisheries (2020), holders of seaweed aquaculture licenses invested US\$ 3.9 million between 2015 and 2019, of which $84 \%$ were devoted to production equipment for cultivation and processing. Centralized solutions for the stabilization and processing of the biomass can contribute to a higher degree of specialization in the value chain. Establishing LFCS may lead to a more efficient use of financial resources towards upscaling the production and
Fig. 1 Norwegian seaweed aquaculture production $(\mathbf{A})$ and value $(\mathbf{B})$. Data from the Directorate of Fisheries (2020)

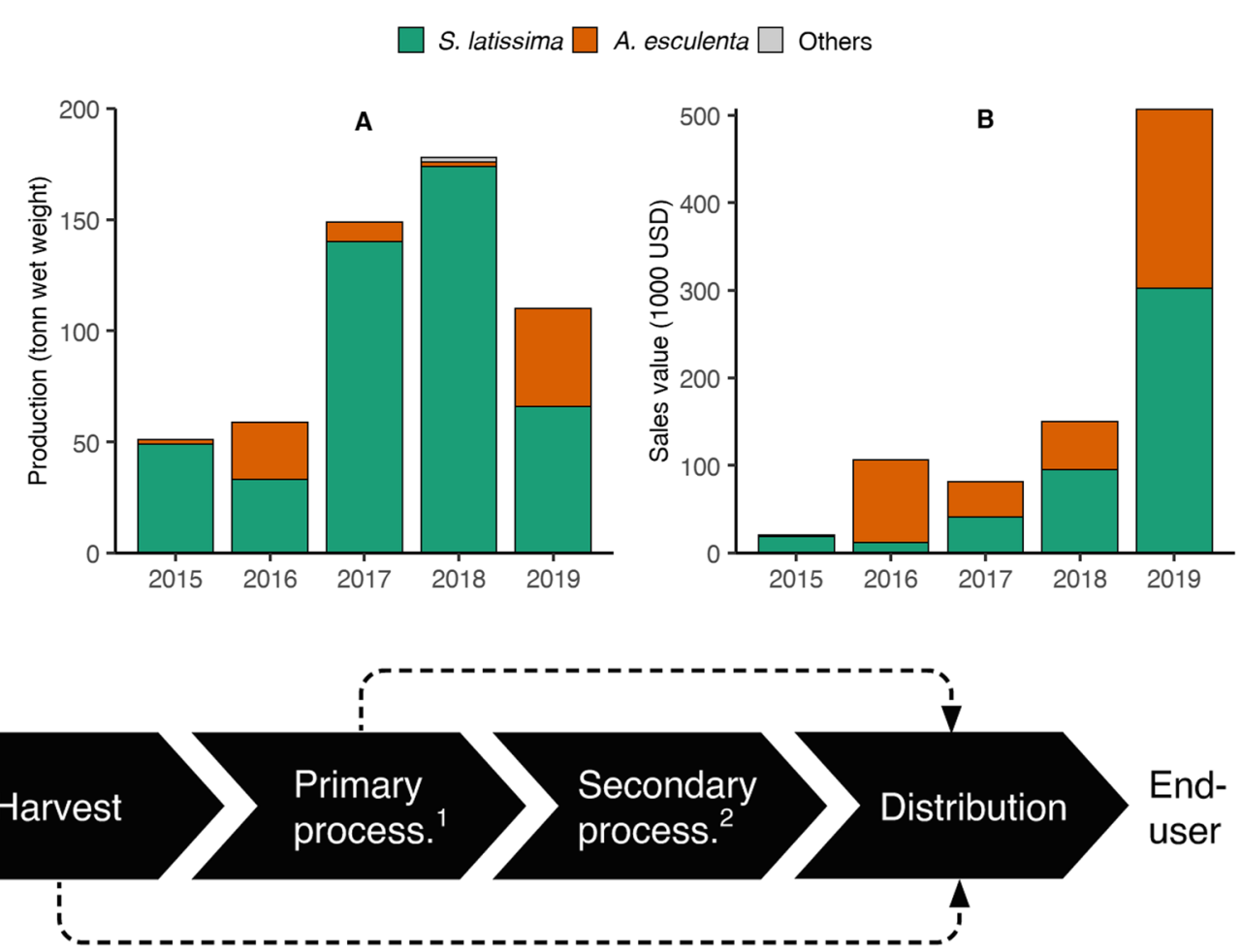

blanching, chopping and grinding). ${ }^{2}$ Secondary processing includes further treatments for the recovery of single or multiple compounds (e.g. fractionation and extraction)
Fig. 2 Schematic overview of the value chain based on cultivated seaweeds. ${ }^{1}$ Primary processing includes stabilization processes and additional steps which may be employed during the production (e.g. 
developing processing strategies for large amounts of seaweed biomass.

The biomass from the respondents is mainly used in food and feed applications to the European market. This confirms that both utilizations have a great potential for creating value from cultivated biomass (Chapman et al. 2015; Wells et al. 2017; Øverland et al. 2019). The raw material can be used as a whole ingredient, e.g. fresh sea vegetable, dried flake and seaweed meal, or in the form of extracts containing single or multiple bioactive compounds. While most of the production is sold in relatively large amounts to industrial players, smaller volumes are used as food products developed by biomass producers themselves and sold directly to the consumer (e.g. dried seaweed condiment). Unlike in several Asian countries, seaweeds have not been an important part of the diet in the Norwegian and generally in Western societies. This resource is now receiving increasing attention from both consumers and the food industry due to an increasing demand for healthy and natural foods that can be produced in a sustainable way. The dialogue with major industrial actors of the food and feed sectors revealed that the national cultivated seaweed production must drastically increase to become a staple food and a common feed ingredient in livestock or aquaculture production. Stable delivery, high quality and competitive price are important factors for the achievement of this industrial potential.

Seaweeds also attract considerable attention as a potential feedstock for other applications, including biofuels, bioplastics and biochemicals, biofertilizers and pharmaceutical products. Biorefinery concepts for cultivated seaweeds aiming at the complete utilization of the raw material and the valorization of both high-value products and waste streams are currently under development (Torres et al. 2019). Cosmetics and nutraceuticals are also important markets for seaweed biomass in Europe (Barbier et al. 2020; van den Burg et al. 2020). The results from the interviews suggest that Norwegian producers have, at present, relatively little connection to these markets. In a recent study, van den Burg et al. (2020) highlighted the importance of developing highvalue products from European cultivated seaweed biomass to avoid the competition with already established industries in Asian countries producing and processing seaweeds at lower costs. Meeting the standards for organic or sustainable certifications (EU organic label, ASC-MSC seaweed standard) may be a way to add value to the cultivated and processed seaweed biomass.

\section{Cultivated seaweeds for food and feed applications}

Using the biomass as food and feed ingredients entails formal requirements regarding their safety (EU 767/2009; EU No. 1881/2006; EU No. 2018/464; Gellenbeck 2012). Although seaweeds are generally regarded as healthy food ingredients, they can also accumulate toxic substances with potentially adverse health effects (Banach et al. 2020). A specific European regulation is under development based on occurrence data on the levels of a broad range of potentially toxic substances in relevant seaweed species and associated health risks from their consumption (Lähteenmäki-Uutela et al. 2021). Meanwhile, seaweed producers must comply with microbiological criteria and monitor levels of heavy metals, inorganic arsenic and iodine (EU No. 2018/464) to support dietary exposure assessment and the further development of adapted regulations. Kelp species such as S. latissima typically contains high levels of iodine which may lead to excessive intakes and potentially adverse health effects upon daily consumption (Stévant et al. 2017a). On the other hand, optimal iodine intake is important for fetal development and development of motoric skills in young children. Iodine deficiency is recognized in European population. Previous studies showed that heat treatments can effectively reduce the iodine content of S. latissima (Stévant et al. 2017a; Nielsen et al. 2020). Seaweeds, especially kelp species, could represent a dietary source of iodine which is relevant in a public health perspective (Andersson et al. 2007). As part of a LFCS, processing methods must be established at a commercial level to minimize the risks associated with potentially hazardous substances and avoid microbial contamination (especially spore-forming bacteria such as Bacillus spp. (Duinker et al. 2020)) to deliver safe products to the market. Seaweeds, and the occurrence of a number of biofouling organisms such as fish and shellfish in open sea cultures, may also provoke allergic reactions in sensitized individuals (Motoyama et al. 2007; Thomas et al. 2019). Consequently, allergic risk assessments are needed for future developments of seaweed-containing food products to the food market at large.

Other important factors for the commercial success of natural food products include flavor and nutritional value, along with color, mouthfeel, freshness, cleanliness as well as traceability and ethical requirements related to the values that condition consumer behavior (Peri 2006). Despite increasing consumer acceptance, seaweed-based food products are still associated with niche markets. The consumer's lack of knowledge and familiarity with this resource and food neophobia are currently major factors limiting the demand for seaweed products (Birch et al. 2019). The development of high-quality products and adapted marketing strategies are key considerations to a broader use of seaweed as food in Europe. The respondent from the food sector emphasizes the need to create positive taste experiences from seaweed and take advantage of current trends on local, sustainable, healthy and vegetarian/vegan foods. In this context, efforts must be made to identify the effects of relevant processing and storage methods on the sensory properties of the products (Stévant et al. 2018, 2020; Sánchez-García 
et al. 2019) and to develop tasty ingredients from seaweeds. A LFCS may act as a platform for collaboration between seaweed producers, processors and industrial users of cultivated biomass to establish quality standards for food products and develop adapted processing strategies.

Results from an in vivo study show that cultivated $S$. latissima can be included in limited amount (ca. 2\%) in a fish feed formulation without negative effects on growth and physiological condition (Granby et al. 2020). However, as generally observed with other seaweed species, the nutritional value of this kelp is quite low following low protein $(<12 \%$ dry weight (DW)) and lipid (ca. 1\% DW) levels (Bikker et al. 2020), an excessive salt content (Özkan Gülzari et al. 2019) and a relatively low digestibility (Bikker et al. 2020). Recent feeding trials conducted with $S$. latissima as a protein source for monogastric animals concluded on the low biological value of this species as feed due to a low protein digestibility and potential hazard for animal health following high salt and iodine levels (Krogdahl et al. 2021). Suitable biorefinery processes would be necessary to improve the nutrient content and digestibility of seaweeds as feed ingredients (see Øverland et al. 2019 and references therein). Feed ingredient being a commodity (low price), a greater value of kelp raw material as feed ingredient may be achieved by taking advantage of the wide range of bioactive substances with utilization as feedstuffs but with application as health enhancers such as complex polysaccharides (e.g. fucoidan and alginate), peptides, polyphenols and pigments associated with functional properties (antioxidant, immune stimulation, prebiotic) (Evans and Critchley 2014; Øverland et al. 2019). Further, the commercial use of cultivated kelp in animal feed has the potential to increase the supply of locally produced raw material and ingredients (Philis et al. 2018; Emblemsvåg et al. 2020). Technical solutions based on low-cost technologies must be developed for the production, stabilization, storage and, when needed, further processing of seaweed biomass to provide a year-round supply of sustainable, safe and affordable feed and food ingredients to industrial producers.

\section{Stabilization methods for cultivated seaweed biomass}

The primary objective of LFCS is to provide technical solutions to handle and process large quantities of seaweed once harvested. This study also aimed at the identification of relevant stabilization processes that should be prioritized. While drying has long been a preferred method of preserving harvested seaweeds, the results highlight the increasing relevance of lactic acid fermentation (also referred to as ensilage by Herrmann et al. (2015) and Cabrita et al. (2017)) as a cost-efficient alternative. Fermented raw material from the respondents from both Norway and abroad are used as food or feed ingredient. This reflects the growing interest from the industry in the development of fermentation techniques adapted from the agricultural sector to seaweed biomass to be processed at a large scale. A rapid decrease in $\mathrm{pH}$ can be successfully achieved by adding a mixture of lactic acid bacteria to fresh biomass of S. latissima and subsequent storage under anaerobic conditions (Herrmann et al. 2015; Cabrita et al. 2017; Campbell et al. 2020). The fresh raw material may also be preserved with the direct use of acid (Sandbakken et al. 2018), although this technique entails greater requirements for environment, health and safety as one must handle a large amount of acid in an industrial process.

The main advantages of lactic acid fermentation are related to the low requirements for energy and advanced equipment. The process can easily be adapted to a mechanized setup in combination with harvesting and on-board treatment of the biomass. This method is therefore highly relevant in commercial cultivation operation, especially in the context of harvesting the entire production in a short time frame due to the onset of biofouling. However, documentation is still lacking regarding the quality and shelf-life of fermented raw material. The consumption of fermentable sugars, including mannitol, the production of acid as well as the formation of a large liquid fraction (between 20 and $30 \%$ of the initial biomass (Herrmann et al. 2015; Stévant 2019) indicate significant changes during fermentation. The process may have positive effects on the quality of the material as food and feed ingredients, e.g. by the degradation of alginates (Moen et al. 1997), resulting in the formation of possible prebiotic properties of subsequent products (oligoalginates) (O'Sullivan et al. 2010), the production of flavor compounds and characteristic taste profiles (Uchida et al. 2014) and the probiotic function of the fermented ingredient. The effects of the fermentation process on potentially toxic substances present in the biomass, e.g. iodine and cadmium, would also need to be documented. The risks associated with uncontrolled microbial growth and the possible occurrence of process-induced food toxicants must be thoroughly assessed. Fermentation can function both as a stabilization method for the intermediate storage of the biomass to be further processed and as a separate processing step. Applied knowledge on microbiology, food science and process technology is necessary to develop targeted fermentation processes to produce safe and tasty products for the consumer and nutritious ingredients for livestock.

Freezing is another possible method for the rapid preservation of fresh seaweed biomass on-board a vessel in combination with harvesting. Large-scale freezing technology is available as it is an established process in e.g. the fishing industry. Freezing and subsequent thawing of S. latissima causes significant drip losses (up to $40 \%$ of biomass) (Stévant 2019). Further processing of frozen biomass requires, therefore, being adapted for total fresh 
material utilization and recovery of bioactive substances from both the solid and liquid fractions. Intermediate storage using refrigerated seawater (RSW) with a temperature close to $0{ }^{\circ} \mathrm{C}$ is another commonly used method in the fishing industry which can extend the shelf-life of fresh raw materials with relatively low energy costs. In this context, technical design is critical to achieve sufficient water exchange and turbulence for the homogeneous cooling of the biomass (Stévant 2019).

Drying is a common method for the stabilization of macroalgal biomass. Dried raw material that are stored adequately have a long shelf-life and are versatile products. Drying at low temperatures $\left(<45^{\circ} \mathrm{C}\right)$ is preferred to preserve bioactive substances (Moreira et al. 2016; Badmus et al. 2019) and avoid product shrinkage during the process (Stévant et al. 2018). As reported by the interviewed respondents, a variety of drying methods is currently employed in the seaweed industry (e.g. convective air-drying, dehumidifier and freeze-drying). High energy consumption and the need for manual handling are repeatedly pointed out as major challenges for drying of seaweed biomass at a commercial scale. Seaweed drying using conventional systems is associated with significant environmental impacts, thus reducing the sustainability of the value chain if the energy source is not carefully chosen (Philis et al. 2018; Halfdanarson et al. 2019; Koesling et al. 2021). The costs associated with the current production scale are also too high to be competitive in a commercial perspective (Emblemsvåg et al. 2020). Alternative technologies, e.g. superheated steam drying and indirect drying systems, combined with technical solutions for energy recovery may increase the process efficiency (Mujumdar 2014). Surplus heat from industrial processes may also be used as an alternative to conventional energy source to reduce costs and increase the sustainability of the process (Philis et al. 2018; Halfdanarson et al. 2019; Koesling et al. 2021). Adapted systems for drying seaweed biomass on a large scale in LFCS should handle fresh biomass shortly after harvest but also stabilized raw material (fermented, frozen) during the rest of the year. Establishing such systems entails high investment costs which often cannot be supported by individual seaweed producers. Therefore, centralizing efficient drying systems in LFCS may benefit several actors of the emerging seaweed industry.

The reception of fresh biomass will only be attractive for actors located in the immediate vicinity, i.e. a few hours transport time from the cultivation site to the landing facility. A broader offer that includes technical and logistical solutions for rapid stabilization (e.g. by fermentation or freezing) at the production site and transport to the plant could benefit seaweed producers in a larger geographical area. Efficient solutions for the intermediate storage of harvested biomass will also provide the opportunity for further processing and value creation outside the harvest season.
Industrial buyers may impose specific requirements regarding e.g. the product form (e.g. flake, powder), food safety or sensory properties (taste, color and texture). This may involve additional steps in the process (e.g. heat treatment, grinding and pulverization) and associated costs or exclude certain processing methods that do not meet product requirements. Optimal processing strategies should be developed to be adapted to each seaweed species and product according to quality requirements of the end-product, rational retail prices to commercial actors and costs associated with individual processing steps (energy, other associated costs). In addition, efficient stabilization methods will allow extending the industrial production based on cultivated macroalgae beyond the harvesting season. The yearround production is an important factor for the economic sustainability of this new bio-based industry. In a short-term perspective, the production of cultivated seaweed biomass may not be sufficient to ensure the continuous operation of LFCS. In this context, the plant may be used by already well-established industries such as the processing of wildharvested seaweeds or seafood species from fisheries and aquaculture.

\section{Framework and prospects for establishing LFCS in Norway and Europe}

By solving challenges associated with biomass stabilization and processing, LFCS has the potential to support the development of a bioeconomy based on cultivated seaweeds at both the regional, national and European levels. The concept of such a facility aroused the interest of interview respondents from all groups (biomass producers, technology suppliers and commercial users). Synergy among stakeholders across sectors is identified as a key factor for the development of the European seaweed sector (van den Burg et al. 2020). Therefore, sharing knowledge (especially across sectors) as well as the investment and operating costs of the facility may allow several actors of the emerging seaweed industry to process their biomass at lower costs and, in turn, increase the local capacity for biomass production.

The Norwegian production and value creation based on cultivated seaweed biomass is currently low, which may limit capital investments for the industrialization of the seaweed sector. The engagement of established industrial stakeholders of the food industry in the emerging European seaweed sector has the potential to provide financial power and a large-scale product distribution (van den Burg et al. 2020). In LFCS, the participation of the food industry is instrumental in defining standards for the quality of seaweed ingredients and developing targeted processing strategies. Public support from local authorities for business development and for establishing such shared facilities can stimulate the involvement of private stakeholders along the value 
chain. Besides significant capital investment, the development and operation of LFCS requires efficient management and organization schemes. Ownership models such as cooperatives or shareholder companies can be relevant alternatives to consider. In addition, the facility may function as a technical center for research and development related to seaweed processing. It may also be involved in the marketing and retail of bulk processed products from seaweeds, such as in agricultural cooperatives.

There are currently over 100 seaweed aquaculture sites in Norway which are not evenly spread along the coast (Fig. 3). Establishing LFCS in active areas for seaweed farming would increase the local production capacity. As mentioned above, the area of influence of LFCS will depend on the service proposed such as the stabilization of fresh biomass on harvesting site as well as the transport from collection place to the facility. It is therefore important to define the roles and functions of such a facility and to consider regional specificities where LFCS are most pertinent when, for example, industrial buyers of seaweed biomass, technology suppliers as well as potential competitors are locally present. The future expansion of seaweed cultivation to industrial levels is expected to move further offshore to avoid the potential conflicts and limitations in coastal areas (Bak et al. 2020). In this case, effective procedures and technology must be developed to harvest, stabilize and further process large amounts of biomass for large-scale industrial applications. One strategy to enable a resourceful development of an offshore seaweed industry would promote the transfer of knowledge and know-how from existing successful industries. For example, Norway has already extensive expertise within offshore maritime operations connected to the oil and gas sector, which could be transferred to the seaweed industry. Besides, there are large amounts of surplus energy from industrial processes (e.g. manufacturing of petroleum products, waste incineration) and solutions have already been implemented for business development based on this secondary energy source, e.g. land-based aquaculture production using excess heat from methanol production in the Møre and Romsdal region (https://www.tbu.no/en/).

Further, the concept of LFCS can be transposed to other European countries that are developing a bioeconomy based on cultivated seaweeds. Besides specific regulations harmonized across EU countries governing product development within food and feed applications, the production and demand for seaweed products may be impacted by other regulatory frameworks specific to each country, such as marine spatial planning and licensing procedures for cultivation at sea, as well as frameworks promoting sustainable and ecoinnovative productions (e.g. reduced taxes on low-carbon
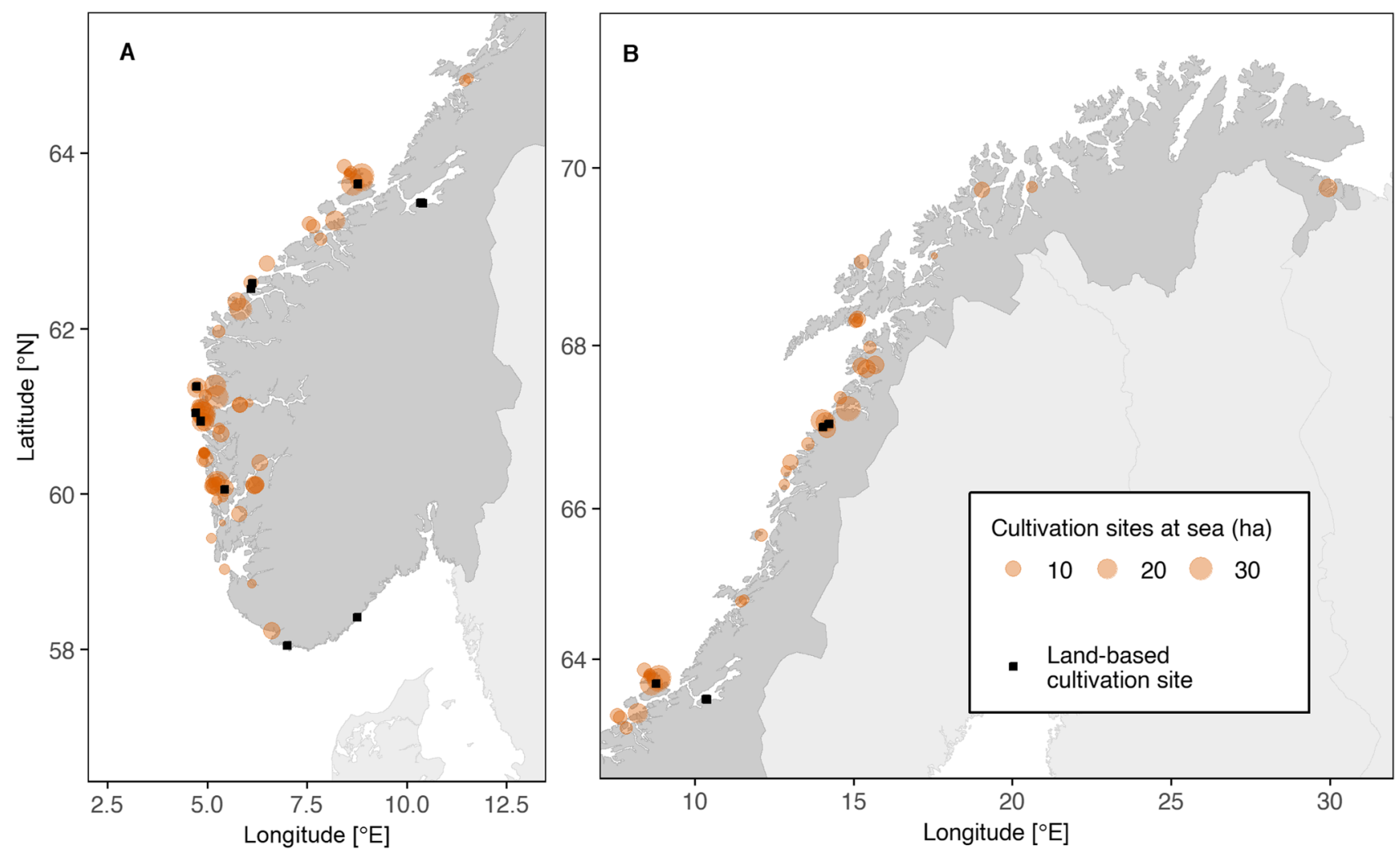

Fig. 3 Seaweed cultivation sites along the coast of southern (A) and northern (B) Norway as of 25 May 2021 (updated from Stévant et al. 2017b). Darker circles indicate several cultivation sites close to each other. Data from the Directorate of Fisheries (2021) 
productions and removing subsidies from competitive highcarbon raw materials) (Lähteenmäki-Uutela et al. 2021).

\section{Conclusions}

This study investigated the concept of a shared facility for landing and processing of seaweed biomass as a potential solution to overcome some of the main challenges to upscale the aquaculture-based production and to establish a sustainable industry based on cultivated biomass in Norway and Europe. The use of seaweeds as commodity for the manufacture of various food and feed products is foreseen in the near future, setting standards for efficient strategies for the production and processing of biomass at a large scale. The stabilization and further processing of fresh biomass is associated with high investment and operating costs. A LFCS will give stakeholders the opportunity to share costs and thus lower their individual financial threshold for establishing efficient solutions for processing large volumes of harvested biomass. Such a plant may also lead to a higher degree of specialization in this emerging industry and a more efficient usage of financial resources which may contribute in return in increasing the pace of upscaling the production. The synergy among stakeholders throughout the entire value chain, i.e. kelp producers, technology suppliers, industrial users of the biomass and research environments, may contribute with innovation but also know-how for the advancement of methods and processes targeted towards end-products. In addition, public support will stimulate the participation of private actors and potential investors. Robust organizational and operational models reflecting individual stakeholders' involvement ought to be established to realize the concept of a shared facility.

Today, food appears to be the main market for Norwegian-grown seaweed although current products are mainly connected to niche markets with a limited distribution. Major industrial actors of the food industry are showing increasing interest to incorporate this sustainable resource as an ingredient for daily consumption. However, knowledge gaps remain concerning efficient post-harvest methods suitable to provide safe, nutritious and flavorful ingredients from seaweeds in sufficient amount for the food industry. Other markets such as dietary supplements, ingredients for animal feed or cosmetic products have also the potential to create value from cultivated biomass. Optimal processes need to be developed for each seaweed species and product based on quality requirements, process costs and purchase price from commercial actors.

Conventional air-drying methods are energy-intensive, lowering the profitability and sustainability of the value chain, which today is limiting their applicability to the processing of large volumes. Alternative methods such as lactic acid fermentation must increase the processing capacity to handle large amounts of biomass in a gentle way (e.g. avoiding oxidation and product quality degradation). Alternative energy sources such as industrial excess heat should also be considered when establishing large-scale processing of seaweed, and these contribute to better profitability and increased sustainability during production.

The concept of LFCS may be transposed to other coastal regions of Europe where the seaweed industry is emerging and adapted to national and/or regional specificities and regulatory frameworks. Future growth of this industry depends on technical innovations to scale up production, reduce processing costs, develop standards for products and production methods and expand and diversify markets for products from cultivated seaweed. The development of efficient processing strategies would need to be paired with technology development for the industrial biomass cultivation at sea, to ensure the economic feasibility as well as the continuous monitoring of environmental impacts of the production to ensure environmentally sustainable business development.

Acknowledgements We are grateful to the interview respondents from the industry for sharing their experience and opinions on key issues related to the production and processing of seaweed.

Author contribution Pierrick Stévant: conceptualization, methodology, formal analysis, investigation, writing (review and editing), visualization, funding acquisition and resources; Céline Rebours: conceptualization, methodology and writing (review and editing).

Funding This work was financed by the Møre \& Romsdal County Council and Møreforsking AS.

Data availability The data consisting of interview transcripts is not available according to General Data Protection Regulation (GDPR) rules.

\section{Declarations}

Ethics approval and consent to participate Personal qualitative data obtain from interviews were anonymized and processed according to GDPR rules. The project and the data processing plan were approved by the Norwegian Centre for Research Data (www.nsd.no, reference: 463969). The respondents' formal written consent to participate was obtained prior to data collection.

Consent for publication The respondents were informed of and agreed to the publication of the results.

Conflict of interest The authors declare no competing interests.

Open Access This article is licensed under a Creative Commons Attribution 4.0 International License, which permits use, sharing, adaptation, distribution and reproduction in any medium or format, as long as you give appropriate credit to the original author(s) and the source, provide a link to the Creative Commons licence, and indicate if changes were made. The images or other third party material in this article are included in the article's Creative Commons licence, unless indicated 
otherwise in a credit line to the material. If material is not included in the article's Creative Commons licence and your intended use is not permitted by statutory regulation or exceeds the permitted use, you will need to obtain permission directly from the copyright holder. To view a copy of this licence, visit http://creativecommons.org/licenses/by/4.0/.

\section{References}

Alexander KA, Angel D, Freeman S, Israel D, Johansen J, Kletou D, Meland M, Pecorino D, Rebours C, Rousou M, Shorten M, Potts $\mathrm{T}$ (2016) Improving sustainability of aquaculture in Europe: stakeholder dialogues on integrated multi-trophic aquaculture (IMTA). Environ Sci Policy 55:96-106

Andersson M, De Benoist B, Darnton-Hill I, Delange F (2007) Iodine deficiency in Europe: a continuing public health problem. World Health Organization, Geneva

Araújo R, Vázquez Calderón F, Sánchez López J, Azevedo IC, Bruhn A, Fluch S, Garcia Tasende M, Ghaderiardakani F, Ilmjärv T, Laurans M, Mac Monagail M, Mangini S, Peteiro C, Rebours C, Stefansson T, Ullmann J (2021) Current status of the algae production industry in Europe: an emerging sector of the blue bioeconomy. Front Mar Sci 7:1247

Badmus UO, Taggart MA, Boyd KG (2019) The effect of different drying methods on certain nutritionally important chemical constituents in edible brown seaweeds. J Appl Phycol 31:3883-3897

Bak UG, Gregersen Ó, Infante J (2020) Technical challenges for offshore cultivation of kelp species: lessons learned and future directions. Bot Mar 63:341

Banach JL, Hoek-van den Hil EF, van der Fels-Klerx HJ (2020) Food safety hazards in the European seaweed chain. Comp Rev Food Sci Food Saf 19:332-364

Barbier M, Araújo R, Rebours C, Jacquemin B, Holdt SL, Charrier B (2020) Development and objectives of the PHYCOMORPH European Guidelines for the Sustainable Aquaculture of Seaweeds (PEGASUS). Bot Mar 63:5

Bikker P, Stokvis L, van Krimpen MM, van Wikselaar PG, Cone JW (2020) Evaluation of seaweeds from marine waters in Northwestern Europe for application in animal nutrition. Anim Feed Sci Technol 263:114460

Birch D, Skallerud K, Paul N (2019) Who eats seaweed? An Australian perspective. J Int Food Agribus Market 31:329-351

Bruhn A, Tørring DB, Thomsen M, Canal-Vergés P, Nielsen MM, Rasmussen MB, Eybye KL, Larsen MM, Balsby TJS, Petersen JK (2016) Impact of environmental conditions on biomass yield, quality, and bio-mitigation capacity of Saccharina latissima. Aquacult Environ Interact 8:619-636

Cabrita ARJ, Maia MRG, Sousa-Pinto I, Fonseca AJM (2017) Ensilage of seaweeds from an integrated multi-trophic aquaculture system. Algal Res 24:290-298

Campbell M, Ortuño J, Ford L, Davies DR, Koidis A, Walsh PJ, Theodoridou K (2020) The effect of ensiling on the nutritional composition and fermentation characteristics of brown seaweeds as a ruminant feed ingredient. Animals 10:1019

Chapman AS, Stévant P, Larssen WE (2015) Food or fad? Challenges and opportunities for including seaweeds in a Nordic diet. Bot Mar 58:423-433

Directorate of Fisheries (2020) Akvakulturstatistikk (tidsserier)-Alger

Directorate of Fisheries (2021) Akvakulturregisteret. http://www. fiskeridir.no/Akvakultur/Registre-og-skjema/Akvakulturregis teret. Accessed 25 May 2021

Duinker A, Kleppe M, Fjære E, Biancarosa I, Heldal HE, Dahl L, Lunestad BT (2020) Knowledge update on macroalgae food and feed safety - based on data generated in the period 2014-2019 by the Institute of Marine Research, Norway. Vol 2020-44. Institute of Marine Research, Bergen, Norway. https://www. hi.no/hi/nettrapporter/rapport-fra-havforskningen-en-2020-44

Emblemsvåg J, Kvadsheim NP, Halfdanarson J, Koesling M, Nystrand BT, Sunde J, Rebours C (2020) Strategic considerations for establishing a large-scale seaweed industry based on fish feed application: a Norwegian case study. J Appl Phycol 32:4159-4169

EU 767/2009 Regulation (EC) No 767/2009 of the European Parliament and of the Council of 13 July 2009 on the placing on the market and use of feed, amending European Parliament and Council Regulation (EC) No 1831/2003 and repealing Council Directive 79/373/EEC, Commission Directive 80/511/EEC, Council Directives 82/471/EEC, 83/228/EEC, 93/74/EEC, 93/113/EC and 96/25/EC and Commission Decision 2004/217/ EC.

EU No 1881/2006 Commission Regulation (EC) No 1881/2006 of 19 December 2006 setting maximum levels for certain contaminants in foodstuffs.

EU No 2018/464 Commission Recommendation (EU) 2018/464 of 19 March 2018 on the monitoring of metals and iodine in seaweed, halophytes and products based on seaweed.

Evans FD, Critchley AT (2014) Seaweeds for animal production use. J Appl Phycol 26:891-899

FAO (2021a) Global aquaculture production. Online query. http://www. fao.org/fishery/statistics/global-aquaculture-production/query/en. Accessed 16 Nov 2020

FAO (2021b) Global capture production. Online query. http://www. fao.org/fishery/statistics/global-capture-production/en. Accessed 03 July 2021

Gellenbeck KW (2012) Utilization of algal materials for nutraceutical and cosmeceutical applications-what do manufacturers need to know? J Appl Phycol 24:309-313

Granby K, Amlund H, Valente LMP, Dias J, Adoff G, Sousa V, Marques A, Sloth JJ, Larsen BK (2020) Growth performance, bioavailability of toxic and essential elements and nutrients, and biofortification of iodine of rainbow trout (Onchorynchus mykiss) fed blends with sugar kelp (Saccharina latissima). Food Chem Toxicol 141:111387

Halfdanarson J, Koesling M, Kvadsheim NP, Emblemsvåg J, Rebours C (2019) Configuring the future Norwegian macroalgae industry using life cycle analysis. In: Ameri F, Stecke KE, von Cieminski G, Kiritsis D (eds) Advances in production management systems. Towards smart production management systems. APMS 2019. IFIP advances in information and communication technology, vol 567. Springer, Cham, pp 127-134

Herrmann C, FitzGerald J, O'Shea R, Xia A, O'Kiely P, Murphy JD (2015) Ensiling of seaweed for a seaweed biofuel industry. Bioresour Technol 196:301-313

Knowler D, Chopin T, Martínez-Espiñeira R, Neori A, Nobre A, Noce A, Reid G (2020) The economics of integrated multi-trophic aquaculture: where are we now and where do we need to go? Rev Aquacult 12:1579-1594

Koesling M, Kvadsheim NP, Halfdanarson J, Emblemsvåg J, Rebours C (2021) Environmental impacts of protein-production from farmed seaweed: comparison of possible scenarios in Norway. $\mathbf{J}$ Cleaner Product 307:127301

Krogdahl Å, Jaramillo-Torres A, Ahlstrøm Ø, Chikwati E, Aasen I-M, Kortner TM (2021) Protein value and health aspects of the seaweeds Saccharina latissima and Palmaria palmata evaluated with mink as model for monogastric animals. Anim Feed Sci Technol 276:114902

Lähteenmäki-Uutela A, Rahikainen M, Camarena-Gómez MT, Piiparinen J, Spilling K, Yang B (2021) European Union legislation on macroalgae products. Aquacult Int 29:487-509 
Miles MB, Huberman AM, Saldaña J (2014) Qualitative data analysis: methods sourcebook, 3rd edn. Sage Publications Inc, Thousand Oaks

Moen E, Horn S, Østgaard K (1997) Alginate degradation during anaerobic digestion of Laminaria hyperborea stipes. J Appl Phycol 9:157-166

Moreira R, Chenlo F, Sineiro J, Arufe S, Sexto S (2016) Drying temperature effect on powder physical properties and aqueous extract characteristics of Fucus vesiculosus. J Appl Phycol 28:2485-2494

Motoyama K, Hamada Y, Nagashima Y, Shiomi K (2007) Allergenicity and allergens of amphipods found in nori (dried laver). Food Addit Contam 24:917-922

Mujumdar AS (2014) Handbook of industrial drying, 4th edn. CRC Press, Boca Raton

Neori A, Chopin T, Troell M, Buschmann AH, Kræmer GP, Halling C, Shpigel M, Yarish C (2004) Integrated aquaculture: rationale, evolution and state of the art emphasizing seaweed biofiltration in modern mariculture. Aquaculture 231:361-391

Nielsen CW, Holdt SL, Sloth JJ, Marinho GS, Sæther M, Funderud J, Rustad T (2020) Reducing the high iodine content of Saccharina latissima and improving the profile of other valuable compounds by water blanching. Foods 9:569

O’Sullivan L, Murphy B, McLoughlin P, Duggan P, Lawlor PG, Hughes H, Gardiner GE (2010) Prebiotics from marine macroalgae for human and animal health applications. Mar Drugs 8:2038

Øverland M, Mydland LT, Skrede A (2019) Marine macroalgae as sources of protein and bioactive compounds in feed for monogastric animals. J Sci Food Agric 99:13-24

Özkan Gülzari Ş, Lind V, Aasen IM, Steinshamn H (2019) Effect of supplementing sheep diets with macroalgae species on in vivo nutrient digestibility, rumen fermentation and blood amino acid profile. Animal 13:2792-2801

Peri C (2006) The universe of food quality. Food Qual Prefer 17:3-8

Philis G, Gracey EO, Gansel LC, Fet AM, Rebours C (2018) Comparing the primary energy and phosphorus consumption of soybean and seaweed-based aquafeed proteins - a material and substance flow analysis. J Cleaner Product 200:1142-1153

Rotter A, Bacu A, Barbier M et al (2020) A new network for the advancement of marine biotechnology in Europe and beyond. Front Mar Sci 7:278

Sánchez-García F, Mirzayeva A, Roldán A, Castro R, Palacios V, García-Barroso C, Durán-Guerrero E (2019) Evolution of volatile compounds and sensory characteristics of edible green seaweed (Ulva rigida) during storage at different temperatures. J Sci Food Agric 99:5475-5482

Sandbakken IS, Sæther M, Funderud J, Aasen IM (2018) Acid preservation of Saccharina latissima for application as a carbon source for fermentation to biofuels and chemicals. J Appl Phycol 30:3581-3588

Stévant P (2019) Seaweeds in food applications: effects of processing on product quality. Ph.D thesis, Norwegian University of Science and Technology (NTNU), Trondheim, Norway

Stévant $\mathrm{P}$, Indergård E, Ólafsdóttir A, Marfaing H, Larssen WE, Fleurence J, Roleda MY, Rustad T, Slizyte R, Nordtvedt TS (2018) Effects of drying on the nutrient content and physicochemical and sensory characteristics of the edible kelp Saccharina latissima. J Appl Phycol 30:2587-2599

Stévant P, Marfaing H, Duinker A, Fleurence J, Rustad T, Sandbakken I, Chapman A (2017a) Biomass soaking treatments to reduce potentially undesirable compounds in the edible seaweeds sugar kelp (Saccharina latissima) and winged kelp (Alaria esculenta) and health risk estimation for human consumption. J Appl Phycol 30:2047-2060

Stévant P, Olafsdóttir A, Déléris P, Dumay J, Fleurence J, Ingadóttir B, Jónsdóttir R, Ragueneau É, Rebours C, Rustad T (2020) Semi-dry storage as a maturation process for improving the sensory characteristics of the edible red seaweed dulse (Palmaria palmata). Algal Res 51:102048

Stévant P, Rebours C, Chapman A (2017b) Seaweed aquaculture in Norway: recent industrial developments and future perspectives. Aquacult Int 25:1373-1390

Thomas I, Siew LQC, Watts TJ, Haque R (2019) Seaweed allergy. J Allergy Clin Immunol Pract 7:714-715

Torres MD, Kraan S, Domínguez H (2019) Seaweed Biorefinery. Rev Environ Sci Bio/technol 18:335-388

Uchida M, Miyoshi T, Yoshida G, Niwa K, Mori M, Wakabayashi H (2014) Isolation and characterization of halophilic lactic acid bacteria acting as a starter culture for sauce fermentation of the red alga nori (Porphyra yezoensis). J Appl Microbiol 116:1506-1520

van den Burg S, Selnes T, Alves L, Giesbers E, Daniel A (2020) Prospects for upgrading by the European kelp sector. J Appl Phycol 33:557-566

Wells ML, Potin P, Craigie JS, Raven JA, Merchant SS, Helliwell KE, Smith AG, Camire ME, Brawley SH (2017) Algae as nutritional and functional food sources: revisiting our understanding. J Appl Phycol 29:949-982

Publisher's note Springer Nature remains neutral with regard to jurisdictional claims in published maps and institutional affiliations. 